\title{
Orogenesis: Cause of Sedimentary Formations
}

\author{
Guy Berthault \\ Polytechnique School Engineer, Paris, France, Member of "La Société Géologique de France” \\ Email: berthault.guy@orange.fr
}

Received 2013

\begin{abstract}
Experiments on stratification discussed here have revealed the mechanical nature of lamination as well as the role of turbulent current as agent of stratification. They challenge Steno's principle that superposed strata are successive sedimentary layers. They show that relative chronology should not be referred to as "stages" but as "sequences" of series. The rock formation studied by Lalomov shows that the duration of sedimentation could be considerably shorter than indicated by the Geological Time Scale. The latter scale corresponds to large marine transgressions and regressions that can result from the shift of polar axis following such major orogeneses as the Caledonian, Hercynian and Alpine.
\end{abstract}

Keywords: Stratification; Lamination; Turbulent Flow; Time of Sedimentation; Orogenesis

\section{Introduction}

Much of sedimentology is based on Nicolas Steno's (1669) principle i.e. that superposition of strata leads to a succession of sedimentary layers[1]. However, some stratification experiments discussed here call for questioning this principle.

As reported to the Académie des Sciences de Paris by Professor George Millot, Berthault (1986, 1988) [2,3] performed several lamination experiments (Figures 1 and 2). In a typical experiment, a sample of friable laminated "Fontainebleau Sandstone" was crushed into sand particles, which were then dropped into a flask. It was observed that a lamination was immediately reconstituted in the ensuing deposit. A reasonable explanation of the latter is that sand is a hetero-granular powder, the mechanics of which is intermediate between solids and distinct liquids. It is well known that liquids stratify according to their density. Moreover, compelling evidence by McKee et al. (1967) [4] strongly suggests that the graded-bedding of stratification results from turbulent flow, the variable velocity of which determining the successive deposit of particles of different sizes.

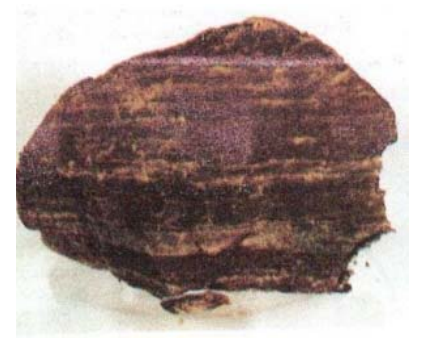

Figure 1. Sample of diatomite.
Further work by Julien et al. (1993)[5], in which a pump circulated sand-laden water in a flume, showed that sand particles indeed deposited accordingly to the velocity of the turbulent current.(Figures 3-5). The sedimentary deposit consisted of superposed and juxtaposed strata which prograded laterally in the direction of the current.

Thus, the turbulent flow generates graded-bedding. When the velocity of the current increases, it becomes erosive, creating erosion surfaces in the deposit. When the desiccation of sediments occurs, joints appear. These results show that the current is an essential agent of stratification, which has been overlooked in conventional stratigraphy. In order to properly determine the genesis of sedimentary rocks, modern experiments must include the role of turbulent flow. Therefore, Steno's principle has to be critically reviewed in light of new experimental data.

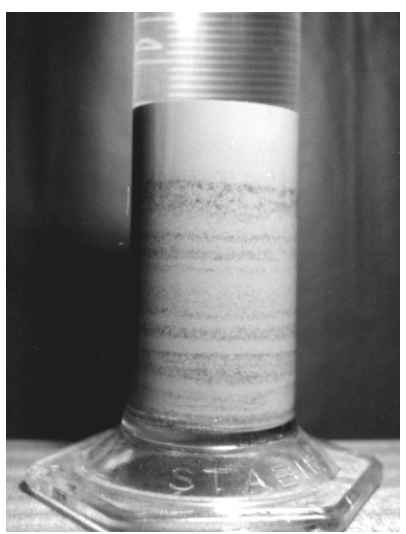

Figure 2. Lamination from flowing of dry sediments. 

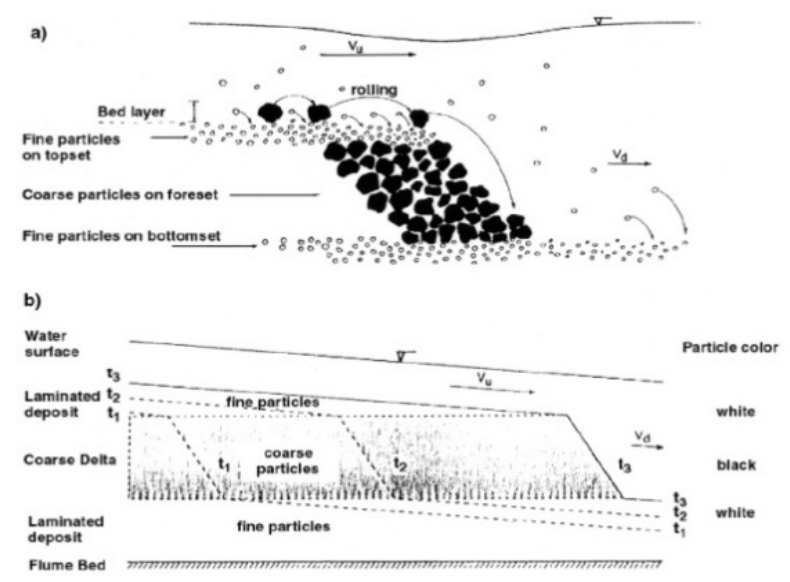

Figure 3. Formation of graded beds.

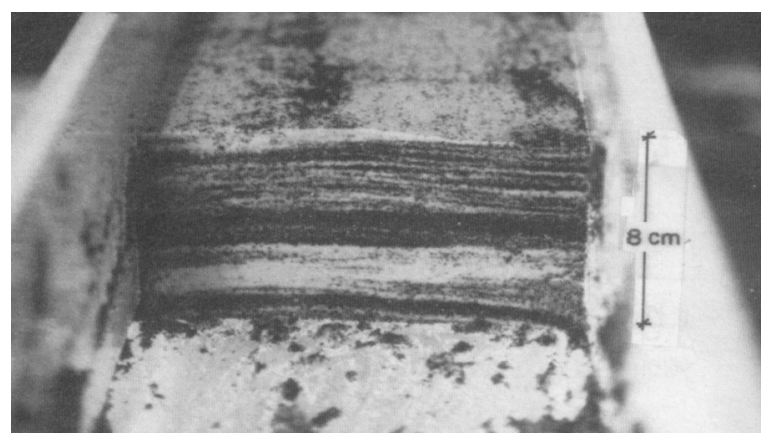

Figure 4. Cross-sectional view of deposit.

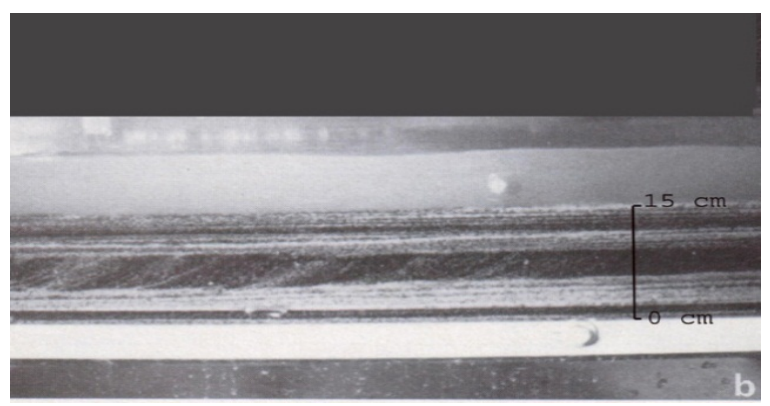

Figure 5. Longitudinal view of deposit.

Golovinski and Walther's law of sequence stratigraphy (cf. Middleton, 1973) [6] states: "Only those facies and facies areas can be superimposed primarily which can be observed beside each other at the present time". As shown in Berthault (2002a, b) [7,8], the superposed and juxtaposed facies constitute a sequence resulting from a marine transgression or regression. A succession of sequences included between an initial transgression and a final regression is a "series".

The data from sequence stratigraphy and the aforementioned experiments show that a series corresponds to a period. Sedimentation, therefore, must be considered as the basic reference of relative chronology instead of stage.

\section{How does the above Affect Absolute Chronology?}

Charles Lyell constructed a geological column, based upon biological 'revolutions' and uniformitarian principles. This was disputed by Gohau (1990) [9] who wrote "Time is measured by the duration of sedimentation, not orogenesis and biological 'revolutions'”.

The radioactive dating of eruptive rocks is based on the phenomenon of spontaneous decay of a radioactive element from a "parent" element into its "daughter" element. A well-known example is uranium (the parent element) which decays into lead (the daughter element). By measuring the quantity of parent element and comparing it to the daughter element, the age of a lava rock can be estimated. But radioactive decay exists in the liquid magma, where gravity exerts a differential separation between parents and daughters according to their density. When the magma erupts on to the Earth's surface, it solidifies into rock. A sample taken from this rock could therefore include unrelated parents and daughters. Moreover, the respective quantity of daughter decay elements produced in the magma cannot be distinguished from those produced in the rock. As a result, the age of the rock cannot be determined confidently. This is why a revision of time based on duration of sedimentation is necessary.

A process to determine sedimentation duration is as follows:

The "Lischtvan-Lebediev" (1959) [10] table gives the critical velocity of current below which particles fall according to their size and the depth of water. Thus, it is possible, from the sizes of particles in a sedimentary rock formation, to determine the velocities of the paleo-currents. These velocities, integrated into the formula of sedimentary mechanics, give the sedimentary transport capacity by units of time and volume. Dividing the volume of the formation under study by this capacity, the time of sedimentation of the formation is obtained (H.A. Einstein). Lalomov (2007) [11] used this technique to estimate the sedimentation duration of various formations in Russia. In particular, Berthault et al. (2011) [12] showed that Cambrian Ordovician sandstone in the St. Petersburg region represents less than $0.05 \%$ of the time attributed to it by the stratigraphic time scale.

This result of $0.05 \%$ does not take into account the velocity of the erosive currents which created such rocks as conglomerates. Experiments on sedimentary slabs (sandstone, shale, limestone) were performed at the Saint Petersburg Institute of Hydrology (Berthault et al., 2010) [13]. Erosion started when the velocity of current reached $27 \mathrm{~m} / \mathrm{s}$. Further experiments are envisioned which should show the time of sedimentation to be faster.

Importantly, Marchal (1996)[14] has demonstrated that mountain orogenesis provoked a shift of the axis of rotation of the Earth triggering large marine series. It is 
significant that, in the geological column since the Cambrian period, eighteen marine series, or systems, are inter-bedded between nineteen orogeneses, which occurred in different places around the Earth.

As reported in the Bulletin of the Museum of Natural History of Paris (1996-1997), the North Pole in the Eocene, before the Himalayan orogenesis, was off the mouth of the river Ienissei in Siberia, by 72 degrees latitude (cf. Marchal, 1996) [14]. After the orogenesis, it was near to its present position resulting in an eighteen degree polar shift.

The direction of transgressions and regressions following each orogenesis corresponds to the succession of resulting sequential facies, such as sandstone, shale and limestone as seen from the surface of the deposit. An example was given in Berthault (2004) [15]. The Tonto group is assigned to Cambrian. It proceeded from the Cadomian orogenesis, at the beginning of the Cambrian; and resulted from a transgression going from the Pacific Ocean in the west to New Mexico in the east. Other directions can be determined from other orogenesis which occurred elsewhere around the Earth.

Contemporaneous marine fauna vary according to depth, latitude, and longitude and such ecological diversification exists in the geological column. The apparent change of fossilized marine organisms from one series to another following an orogenesis can result from different fauna, transported by water flows from different locations resulting from successive orogeneses. What has been attributed to biological change could be ecological in nature explained by fauna coming from different orogeneses, taking into account the short time of sedimentation.

\section{Conclusions}

In conclusion, a relationship can be established between cause and effect. Orogenesis, which can result from periodic mantle plumes (Rampino \& Prokoph, 2013) [16], causes shifting of the polar axes, which then leads to consecutive marine series and sedimentary deposits. The duration of the latter is much shorter than given by the stratigraphic time scale and so calls for a serious revision of the foundation of historical geology (Berthault, 2012)[17].

\section{REFERENCES}

[1] N. Steno and N. Stensen, "Canis Carchariae Dissectum Caput,KIU” Aus., lat. u. engl. The earliest geological treatise, 1667.

[2] B. G. Sedimentology, "Experiments on Lamination of Sediments, Resulting from a Periodic Graded-Bedding Subsequent to Deposit,” Comptes Rendus De L Academie
Sciences, Paris, t. 303, Série ii, No. 17, 1986.

[3] G. Berthault, "Sedimentation of a Heterogranular Mixture. Experimental Lamination in Still and Running Water," Comptes Rendus De L Academie Sciences, Paris, t. 306, Série ii, 1988, pp. 717-724.

[4] E. D. McKee, E. J. Crosby, H. L. Berryhill, Jr, "Flood Deposits, Bijou Creek, Colorado, June 1965,” Journal of Sedimentary Petrology, Vol. 37, No. 3, 1967, pp. 829-851.

[5] F. Y. Julien and L. Y. Berthault G, "Experiments on Stratification of Heterogeneous Sand Mixtures," Bulletin Société Géologique de France, 1993, Vol. 164. No. 5, pp 649-660.

[6] G. V. Middleton, "Johannes Walther's law of the correlation of facies,"Geological Society of America Bulletin, 1973 - Geological Soc America.

[7] G. Berthault, "Analysis of Main Principles of Stratigraphy,” Lithology and Mineral Resources, Vol. 37, No. 5, 2002, pp. 509-515. doi:10.1023/A:1020220232661

[8] G. Berthault, "Geological Dating Principles Questioned Paleohydraulics a New Approach,”Journal of Geodesy and Geodynamics, Vol. 22,No. 3, 2002, pp. 19-26.

[9] G. Gohau, Une histoire de la géologie. Paris : Seuil, P.277. 1990.

[10] Lischtvan-Lebediev, "Gidrologia i gidraulika v mostovom doroshnom. Straitielvie”, Leningrad,1959.

[11] A. Lalomov, "Reconstruction of Paleohydrodynamic Conditions during the Formation of Upper Jurassic Conglomerates of the Crimean Peninsula," Lithology and Mineral Resources,Vol. 42, No. 3, 2007, pp. 268-280. doi:10.1134/S0024490207030066

[12] G. Berthault, A. Lalomov and M. A. Tugarova, "Reconstruction of Paleolithodynamic Formation Conditions of Cambrian-Ordovician Sandstones in the Northwestern Russian Platform,” Lithology and Mineral Resources, Vol. 46, No. 1, 2011, pp. 60-70. doi:10.1134/S0024490211010020

[13] G. Berthault, A. L. Veksler, V. M. Donenberg and A. Lalomov, "Research on Erosion of Consolidated and Semi-Consolidated Soils by High Speed Water Flow," Izvestia VMG, Vol. 257, 2010, pp. 10-22.

[14] C. Marchal, "Earth's Polar Displacements of Large Amplitude. A Possible Mechanism,” Bulletin du Museum National d'Histoire Naturelle. Paris. $4^{\text {th }}, 18$, Errata Geodiversitas, Vol . 19, No. 1, 1997, p. 139.

[15] G. Berthault, "Sedimentological Interpretation of the Tonto Group Stratigraphy. Grand Canyon Colorado River,” Lithology and Mineral Resources, Vol. 39, No. 5, 2004, pp. 504-508. doi:10.1023/B:LIMI.0000040737.85572.4c

[16] M. R. Rampino and A. Prokoph, "Are Mantle Plumes Periodic?” EOS Transactions American Geophsical Union, Vol. 94, No. 12, 2013, pp. 113-120. doi:10.1002/2013EO120001

[17] G. Berthault, "Towards a Refoundation of Historical Geology,” Georesources, 2012, pp. 4-36. 